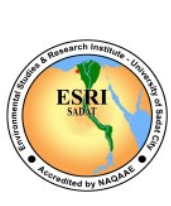

University of Sadat city,

Environmental Studies and Research

$5^{\text {Th }}$ International Conference

"New Horizons Towards Comprehensive Development"

Hurghada, Egypt 1-4 April 2019

Journal of Environmental Studies and Researches (2019), 9(A):92 - 98

\title{
PRODUCTION OF BIOGAS FROM SOLID ORGANIC WASTES THROUGH ANAEROBIC DIGESTION
}

\author{
Abdall El-Harby, M.A.El-Howeity and M.H.Aly
}

\begin{abstract}
A naerobic digestion treatments have often been used for biological stabilization of solid wastes. These treatment processes generate biogas which can be used as a renewable energy sources. Recently, anaerobic digestion of solid wastes has attracted more interest because of current environmental problems, most especially those concerned with global warming. Thus, laboratory-scale research on this area has increased significantly. In this study, the production of biogas from solid wastes according to its origin via various anaerobic technologies was presented. Food, agriculture, garbage and chicken manure were investigated for producing biogas production under mesophlilc conditions. Animal manure was added as a starter to facilitate the anaerobic digestion process. The obtained results show that, the biogas produced ranged between 23.32.to50.11.L/L. The highest biogas yield was observed with chicken manure waste to50.11.L/L compared to other wastes.
\end{abstract}

Keywords: Anaerobic digestion, Biogas, renewable energy

الملخص العربي

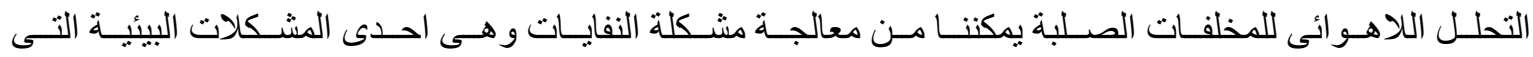

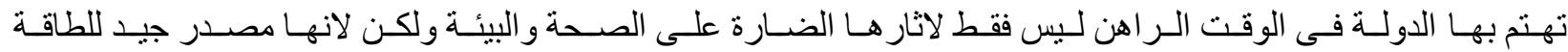

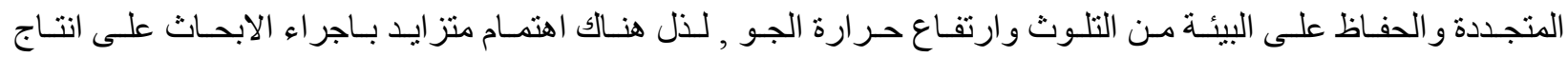

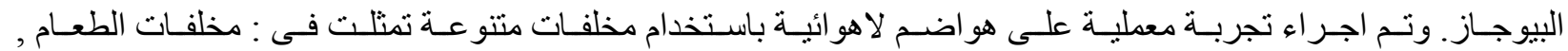

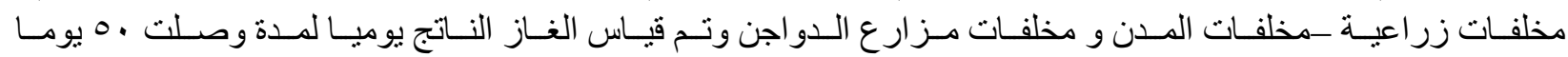

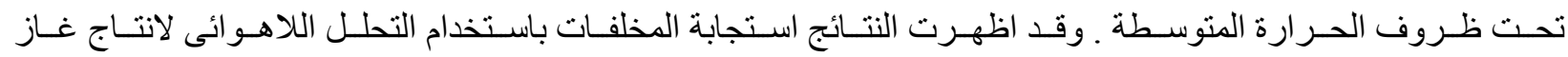

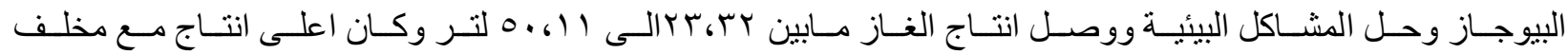
الدو اجن مقارنة مع باقى المعاملات المان.

\section{INTRODUCTION:}

Million tons of solid waste is produced annually from municipal, industrial, and agricultural sources. The indiscriminate decomposition of these organic wastes results in large-scale contamination of land, water, and air. Of all the forms of solid organic waste, the most abundant is animal dung primarily from small farms, and it is from these farms that the pollution problem originating from waste disposal is more intense. 
Egypt at about 13.8 million tons, distributed as follows, 9.6\% paper, $6.2 \%$ plastic, $3.7 \%$ metals, $3.5 \%$ glass and $77 \%$ other materials (Ministry of Local Development in 2010). The rate of municipal solid waste generation in Egypt fluctuates between $1.0-1.3 \mathrm{~kg} /$ capita/day in big cities, $0.5-0.8 \mathrm{~kg} / \mathrm{capita} /$ day in medium cities and about $0.25 \mathrm{~kg} /$ capita/day in small cities and rural areas (Saber, 2001). The indiscriminate decomposition of these organic wastes results in large-scale contamination of land, water, and air of all the forms of solid organic waste, the most abundant is animal dung primarily from small farms, and it is from these farms that the pollution problem originating from waste disposal is more intense. Research continues to focus on the treatment of cattle dung for biogas production and possible optimization methods which could be used to enhance the production for practical applicability of the technology.

Anaerobic digestion for biogas production has become a worldwide focus of research, because it produces energy that is renewable and environmentally friendly. Special emphasis was initially focused on anaerobic digestion of MSW for bioenergy production about a decade ago (Braber 1995; Kiely et al. 1997). Anaerobic biological treatment can be an acceptable solution because it reduces and stabilizes solid wastes volume, produces biogas comprising mainly methane and carbon dioxide, and traces amount of other gases (Stroot et al. 2001). In addition to biogas, a nutrient-rich digestive is also produced which provide either fertilizer or soil conditioner properties. Biological treatment of MSW to biogas by anaerobic digestion processes including source sorted and mechanically sorted MSW has been previously discussed (Gunaseelan 1997).

A laboratory scale batch anaerobic digestion of municipal garbage was studied by Rao et al. (2000) at temperatures of $25{ }^{\circ} \mathrm{C}$ and $29{ }^{\circ} \mathrm{C}$, with a concentration range between 45 and $135 \mathrm{~g} \mathrm{TS} / \mathrm{L}$. They found out that the methane content from the biogas varied between 62 and $72 \%$, and a conversion efficiency of about $85 \%$ was obtained. In a similar study, Rao and Singh (2004) investigated the batch digestion of municipal garbage under room temperature $\left(26 \pm 4{ }^{\circ} \mathrm{C}\right)$ to estimate its bioenergy potential and conversion efficiencies at an HRT of 15 days. They reported a high yield of $0.56 \mathrm{~m} 3$ biogas $\mathrm{kg}-1$ VS added with $70 \%$ methane content and a VS reduction of $76.3 \%$. These results demonstrated that municipal garbage has a high potential to be a bioenergy source.

The objective of this study was to describe the organic wastes digestion in the laboratory conditions with the aim of characterization of the basic technological parameters such a specific biogas production and biodegradability of substrates.

\section{MATERIALS AND METHODS}

\section{Production of biogas from different municipal solid wastes:}

A laboratory experiment was design to utilize and evaluate the behavior of four different municipal solid wastes for biogas production and its methane and carbon dioxide contents were measured .Fine pulverized $\mathrm{CaCo}_{3}$ was thoroughly mixed with the garbage to reach $10 \%$ of the total solids in each fermentor. The mixtures were put in 10.5 liter fermentors and kept in a walk in incubator $\left(10 \mathrm{~m}^{3}\right.$ capacity) at $35-37^{\circ} \mathrm{C}$ as 
shown in the Fig (1). The amount of the fermenting material was $1.250 \mathrm{~kg}$. Four biogas mixtures were prepared as follows:

T1: Garbag waste $(\mathrm{GW}) 1.250 \mathrm{~kg}+0.5$ liter of starter $+755.0 \mathrm{ml}$ liliter of water

T2: agriculture waste (AW) $1.250 \mathrm{~kg}+0.5$ liter of starter $+755.0 \mathrm{ml}$ liliter of water,

T3: Fresh food waste (FW) $1.250 \mathrm{~kg}+0.5$ liter of starter+755.0 ml liliter of water and T4:

Chicken manure +0.5 liter of starter $+755.0 \mathrm{ml}$ liliter of water.

Biogas was daily measured, while its content of $\mathrm{CH}_{4}$ and $\mathrm{CO}_{2}$ were estimated weekly throughout the experimental period according to the methods described by (Estefanous, 1987).

\section{RESULTS AND DISCUSSION}

\section{EVALUATION OF BIOGAS PRODUCTION}

According to the results, daily and cumulative biogas production either liter/digester/day or liter/liter/day during the fermentation period of different treatments of municipal solid waste are illustrated by Figures (1,2 and 3). Data show that the fermented materials did not produce any biogas during the first day. Biogas production by anaerobic bacteria needs a lag period to these bacteria (nearly one day) to begin production of biogas. The daily production of biogas showed fluctuation in both fermented materials. The daily production gas from the digesters (T4) chicken manure was more superior 1.01per day with standard deviation 0.197 followed by food waste (T3) daily gas production was 0.843 with standard deviation 0.055 then garbage waste produced 0.641 with standard deviation 0.07 . Moreover agriculture waste gave the latest daily gas production 0.446 with standard deviation 0.218 . Furthermore, the gas production was high at the beginning up to the second day then decreased and showed fluctuation thereafter. The highest biogas production was observed at the $34^{\text {th }}$ and $23^{\text {th }}$ day in (T1, T2) and the $28^{\text {th }}$ and $26^{\text {th }}$ in (T3, T4). Daily biogas production rapidly decreased after the $26^{\text {th }}$ and $34^{\text {th }}$ day and then slowly to reach the minimum level at the end of the fermentation course. The cumulative biogas yield was in the order from the highest biogas yield to the lowest biogas yield in T4, T3, T1 and T2. Results of the biogas production yield show that the follows in the order $\mathrm{T} 4>\mathrm{T} 3>\mathrm{T} 1>\mathrm{T} 2$ with values; 50.11, 42.18, 32.05 and 23.32 respectively. The higher and longer production rate of biogas in case of anaerobic digestion of $\mathrm{T} 4$ due to effective chicken manure so that the rate of decomposing increased. These results are in agreement with that of (Chomini et al., 2015) they found that, digestion of chicken manure as a monosubstrate showed better results when compared to the digestion of animal manure also as a mono substrate.

As observed from the results, anaerobic degradation in all the four digesters followed a similar trend; gradually increasing at the start of the process, reaching a peak and then gradually decreasing until the end of the experiment. The reason for such behavior is the direct relation between biogas yield and specific growth rate of methanogenic bacteria in batch anaerobic digesters (Nordberg and Edström, 2005). The initial general increase in biogas production is in conformity with a research conducted by ( Li et al., 2011) which attributed the change to the presence of readily biodegradable organic matter and a considerable population of methanogens in all the digestion 
substrates.

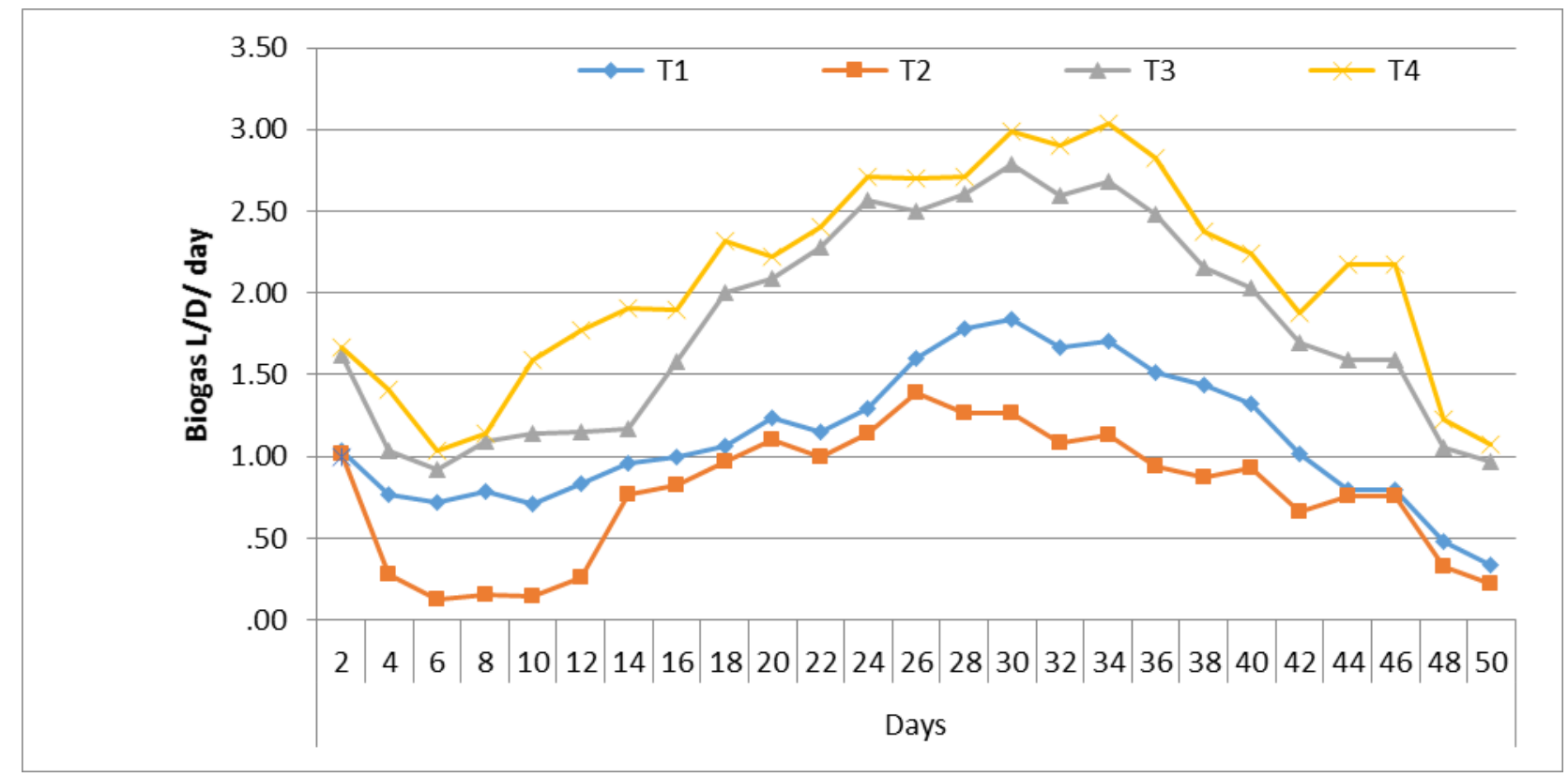

Figure (1) Daily biogas production from anaerobic digesters of different wastes for 50 days.

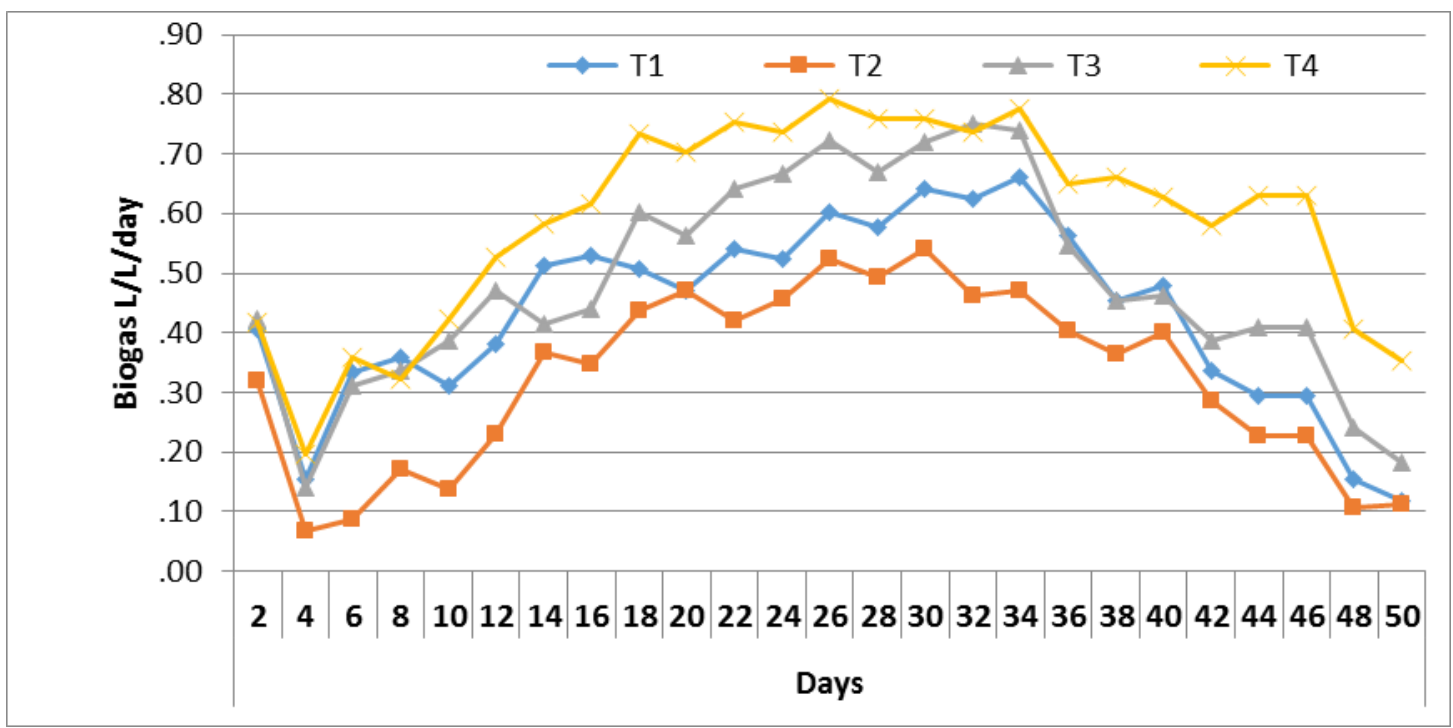

Figure (2) Daily biogas production from anaerobic digesters of different wastes for 50 days .

( T1:Garbag waste, T2 : Agriculture waste ,T3: Food waste and T4: Chicken manure)

The gradual decline in gas production recorded between the sixth and tenth week meshes well with research conducted by (Xie et al., 2011). This is partly due to the low content readily biodegradable organic compounds in the slurry. Food waste was more effective for biogas production for its high degradability and biogas yield. These results agree with, Zhang et al. (2007) conducted a batch anaerobic digestion test to investigate the biodegradability of FW at an HRT of 10 and 28 days. In the study, the highest methane yield of $0.435 \mathrm{~m}^{3} \mathrm{~kg}^{-1} \mathrm{VS}$ was obtained at the end of the 28-days digestion with VS removal of $81 \%$, which is followed by $0.348 \mathrm{~m}^{3} \mathrm{~kg}^{-1} \mathrm{VS}$ at the end of 10-day digestion. These results indicated that FW was a good alternative substrate for anaerobic digestion because of its high degradability and biogas yield. In another study, Forster Carneiro et al. (2008b) experimentally study the biomethanization 
procedure of $\mathrm{FW}$ in six reactors with three different total solid percentages $(20 \%, 25$ $\%$, and $30 \%$ TS) and two different inoculum percentages (20-30\% of mesophilic sludge). The study was designed to select the initial performance parameters (total solid and inoculum contents) in a lab-scale reactor and later, to validate the optimal parameters in a lab-scale batch reactor. The best performance for $\mathrm{FW}$ treatment and the methane generation was the reactor with $20 \%$ TS and $30 \%$ of inoculum. They observed a methane yield of $0.49 \mathrm{~m} 3 \mathrm{~kg}-1 \mathrm{VS}$ added between 20 and 60 days during this operation. In addition, the lab-scale batch reactor shows a classical waste removal with high value of methane yield of $0.22 \mathrm{~m} 3 \mathrm{~kg}-1 \mathrm{VS}$ added. Finally, they proposed a protocol to improve the start-up phase for dry thermophilic anaerobic digestion of $\mathrm{FW}$. Garbage waste was moderate effect for biogas production compared with chicken and food wastes. El-Housseini (1983) found that the garbage mixing with sewage sludge produced biogas within the first day whereas, moistening the garbage with water required 9 to 23 days to generate the biogas such period was needed for proliferation of fermenting bacterial populations effective counts. Vindis et al. (2008) studied biogas production with the use of mini digester and reported that the highest biogas and methane yield was achieved in case of $(75 \%$ sugar beet $+25 \%$ maize). The lowest biogas yield was in case of (50\% sugar beet $+50 \%$ maize), after twenty days the anaerobic digestion is mostly finished. However, after 35 days the amount of biogas was very low.

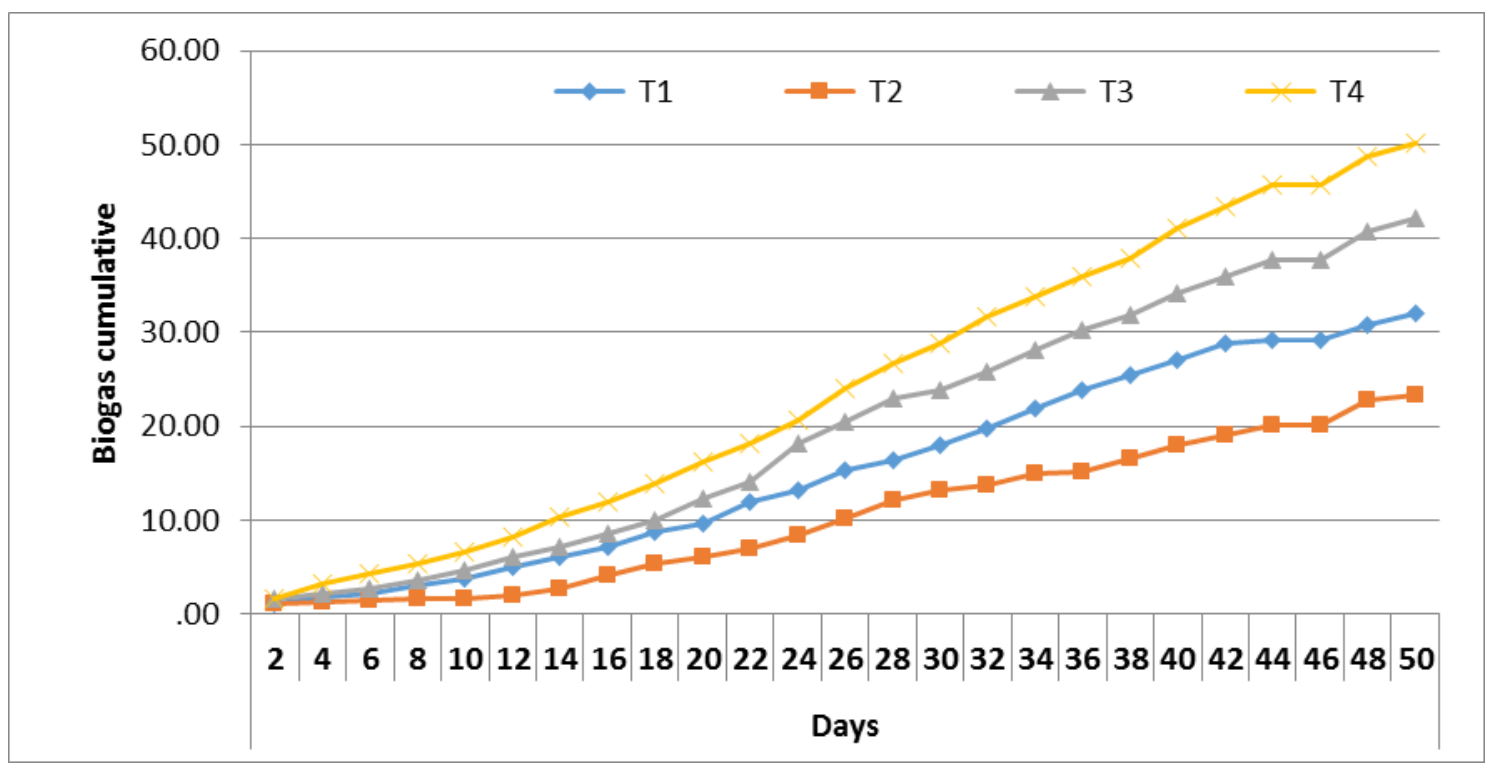

Figure (3) Cumulative biogas production from anaerobic digesters of different wastes for 50 days.

( T1: Garbag waste, T2 : Agriculture waste ,T3: Food waste and T4: Chicken manure)

On the other hand, Rao et al. (2000) observed that, digestion of municipal garbage at temperatures of $25{ }^{\circ} \mathrm{C}$ and $29{ }^{\circ} \mathrm{C}$, with a concentration range between 45 and $135 \mathrm{~g} \mathrm{TS} / \mathrm{L}$. in a laboratory scale batch anaerobic They found out that the methane content from the biogas varied between 62 and $72 \%$, and a conversion efficiency of about $85 \%$ was obtained. In a similar study, Rao and Singh (2004) investigated the batch digestion of municipal garbage under room temperature $\left(26 \pm 4{ }^{\circ} \mathrm{C}\right)$ to estimate its bioenergy potential and conversion efficiencies at an HRTof 15 days. They reported a high yield of $0.56 \mathrm{~m}^{3}$ biogas $\mathrm{kg}^{-1} \mathrm{VS}$ added with $70 \%$ methane content and a VS 
reduction of $76.3 \%$. These results demonstrated that municipal garbage has a high potential to be a bioenergy source.

Almoustapha et al. (2009) reported in their study that although biogas production began at the 8th day, the gas became combustible only at the 11th day. As of the 48th, day the biogas production began to decline steadily. The total volume of biogas produced after 65 days was $151.4 \mathrm{~m} 3$, that is, $2.6 \mathrm{~m} 3 /$ day. Budiyono et al. (2009) reported that biogas production was very slow at the beginning and at the end period of observation. The biogas production rate in batch condition is directly corresponds to specific growth rate of methanogenic bacteria in the biodigester (Nopharatana et al. 2007). Ahn and Forester (2002) reported that the average daily and cumulative biogas production was in all test units showed rapid biogas production for the first 2 days, followed by a rapid decrease in biogas production between days 2 and 4 . The high initial biogas production for days 1 and 2 was due to the preferential digestion of readily biodegradable organic materials like carbohydrates. The dissipation of the readily degradable materials may have caused temporary biogas production decrease between days 2 and 4 . These results are in agreement with results reached in the experiments conducted by Chomini $\boldsymbol{e t}$ al. (2015) as detailed in the literature, which showed that a 1:1 mix of poultry manure and cow dung gave better yield of biogas than each digested singly as a monosubstrate.

\section{REFERENCES}

- Ahn, J. H. and Forester, C.F. (2002). The effect of temperature variations on the performance of mesophilic and thermophilic anaerobic filters treating a simulated papermill wastewater. Process Biochemistry, 37, (6): 589594

- Almoustapha, O.; Kenfack. S. and Rasolodimby. J. M. (2009). Biogas production using water hyacinths to meet collective energy needs in a sahelian country. Field Actions Sci. Rep., 2: 27-32.

- Braber K (1995) Anaerobic digestion of municipal solid waste: a modern waste disposal option on the verge of breakthrough. Bio Bioener 9:365.

- Bouallagui, H., Lahdheb, H., Ben Romdan, E., Rachdi, B., \& Hamdi, M. (2009). Improvement of fruit and vegetable waste anaerobic digestion performance and stability with co-substrates addition. Journal of Environmental Management, 90(5), 1844-1849.

- El-Housseini, M. (1983). Fermentation of city refuses under anaerobic conditions. Ph. D.Thesis, Ain Shams Univ. Cairo, Egypt

- Estefanous, A.N. (1987). Microbiological studies on biogas production from city refuse. M.Sc., Thesis Fac. Agric., Moshtohor, Zagazig University.

- Gunaseelan VN (1997) Anaerobic digestion of biomass for methane production: a review. Bio Bioener 13:83-114.

- Kiely G, Tayfur G, Dolan C, Tanji K (1997) Physical and mathematical modelling of anaerobic digestion of organic wastes. Water Res 31:534.

- Li, J., Jha, A. K., He, J., Ban, Q., Chang, S., \& Wang, P. (2011). Assessment of the effects of dry anaerobic co-digestion of cow dung with waste water sludge on biogas yield and biodegradability. International Journal of Physical Sciences, 6(15), 3723-3732.

- Ministry of Local Development (2010). Information Reports. - Waste problem in Egypt....reality and possible solutionll. http: //www.idsc.gov.eg. 
- Nordberg, and M. Edström. (2005). Co-digestion of energy crops and the source-sorted organic fraction of municipal solid waste. Water Science and Technology, 52(1-2), 217222.

- Nopharatana, A.; Pullammanappallil, P.C. and Clarke, W.P. (2007). Kinetics and dynamic modeling of batch anaerobic digestion of municipal solid waste in a stirred reactor. Waste Manage., 27: 595-603.

- Rao MS, Singh SP, Singh AK, Sodha MS (2000) Bioenergy conversion studies of the organic fraction of MSW: assessment of ultimate bioenergy production potential of municipal garbage. Appl Ener 66:75-78.

- Rao M, Singh S (2004) Bioenergy conversion studies of organic fraction of MSW: kinetic studies and gas yield-organic loading relationships for process optimisation. Biores Technol 95:173-185.

- Stroot PG, McMahon KD, Mackie RI, Raskin L (2001) Anaerobic codigestion of municipal solid waste and biosolids under various mixing conditions-I. digester performance. Water Res 35:1804- 1816.

- Saber, M. (2001). Perspectives on municipal solid waste management in Egypt. Cairo, Egypt: National Research Center.

- Vindis, P.; Mursec, B. ; Rozman, C. ; Janzekovic, M. and Cus, F. (2008). Biogas production with the use of mini digester. J. of Achievements in Materials and Manufacturing Engineering, 28

- Xie, S., P. G. Lawlor, J. P.Frost, Z.Hu, and X. Zhan (2011). Effect of pig manure to grass silage ratio on methane production in batch anaerobic co-digestion of concentrated pig manure and grass silage. Bioresource Technology, 102(10), 5728-5733.

- . Zhang R, El-Mashad HM, Hartmann K, Wang F, Liu G, Choate C, Gamble P (2007) Characterization of food waste as feedstock for anaerobic digestion. Biores Technol 98:92. 